\title{
Nutritional management in an elderly man with esophageal and gastric necrosis after caustic soda ingestion: a case report
}

This article was published in the following Dove Press journal:

Therapeutics and Clinical Risk Management

4 February 2016

Number of times this article has been viewed

Mariangela Rondanelli,' Gabriella Peroni,' Alessandra Miccono, ${ }^{2}$ Fabio Guerriero, ${ }^{3}$ Davide Guido, ${ }^{3,4}$ Simone Perna'

'Department of Public Health, Neuroscience, Experimental and Forensic Medicine, Endocrinology and Nutrition Unit, University of Pavia, Azienda di Servizi alla Persona di Pavia, Pavia, ${ }^{2}$ Department of Clinical Sciences, Faculty of Medicine and Surgery, University of Milano-Bicocca, Milan, ${ }^{3}$ Azienda di Servizi alla Persona di Pavia, ${ }^{4}$ Department of Public Health, Neuroscience, Experimental and Forensic Medicine, Biostatistics and Clinical Epidemiology Unit, University of Pavia, Pavia, Italy

\section{Video abstract}

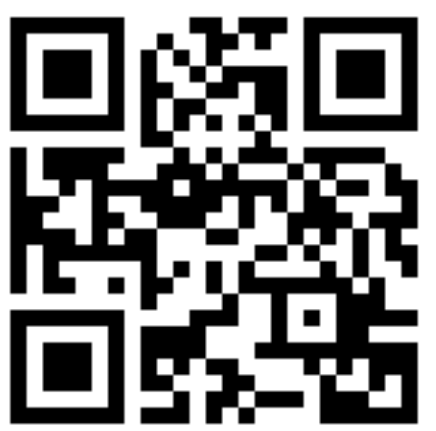

Point your SmartPhone at the code above. If you have a QR code reader the video abstract will appear. Or use: http://youtu.be/YG3pP6Gc-8U

Correspondence: Simone Perna Department of Public Health, Neuroscience, Experimental and Forensic Medicine, Section of Human Nutrition and Dietetics, University of Pavia, Azienda di Servizi alla Persona di Pavia, Via Emilia I2, Pavia, Italy Tel +3938238 I706 Email simoneperna@hotmail.it
Abstract: The ingestion of corrosive industrial chemical agents, such as caustic soda, that are mostly used for household cleaning, usually occurs accidentally or for suicidal purposes. Multiple protocols are based on documented success in preventing impending complications. In this study, we present a case of a 70-year-old man who swallowed caustic soda in a suicide attempt, causing a development of strong esophageal and gastric necrosis with subsequent gastrectomy and digiunostomy. Initially, the recommended nutritional approach was via percutaneous endoscopic jejunostomy by a polymer and high-caloric formula, with an elevated content of soluble fiber. After 5 months, the medical team removed the percutaneous endoscopic jejunostomy and the patient switched from enteral to oral nutrition. In this step, it was decided to introduce two oral, high-caloric supplements: an energy supplement in powder, based on maltodextrin, immediately soluble in foods or in hot/cold drinks and a high-energy and protein drink, enriched with arginine, vitamin C, zinc, and antioxidants. Oral administration (per os) was well tolerated by consuming homogenized food mixed in water. After 1 month, the patient was discharged from the hospital and was able to eat a regular meal.

Keywords: nutritional management, enteral nutrition, gastric necrosis, esophageal necrosis, nutritional supplementation, elderly, caustic soda ingestion

\section{Introduction}

Caustic soda is an alkaline-based substance. Tissue contact with alkaline $\mathrm{pH}$ leads to liquefactive necrosis. Distal esophageal injury is more likely after ingestion of liquids, rather than solids, as they travel further. ${ }^{1}$ The immediate injury consists of acute necrosis, hyperemia, and edema of the aerodigestive tract, leading to vascular thrombosis. In all, 2-4 days post injury, the superficial layer of necrotic mucosa will be sloughed. First, this may lead to either perforations or scarring and, second, contractures due to fibroblast regeneration and production of collagen. Some patients develop long-term problems, principally oral, pharyngeal, and esophageal strictures. Treatment schemes for caustic injuries vary, and no consensus exists. Multiple protocols were formulated based on documented success in preventing impending complications, although a paucity of randomized trials have assessed any of these interventions. ${ }^{2}$ These patients develop malnutrition if they do not follow a personalized nutritional support, but no guidelines are available. A key point is the fitting choice of a main nutritional support via percutaneous endoscopic gastrostomy/percutaneous endoscopic jejunostomy (PEJ) or nasogastric tube. Another aspect to consider is the use of specific formulas to integrate the fitting nutritional needs for each patient. Hence, the monitoring must be considered to determine the transition from enteral to oral nutrition and the route of administration of the food more adequately. 
Given this background, this paper reports the nutritional management of an elderly man who swallowed caustic soda in a suicidal attempt, causing the development of strong esophageal and gastric necrosis with subsequent gastrectomy and digiunostomy.

\section{Case report}

A 70-year-old man was hospitalized in the Institute of Geriatric Rehabilitation Santa Margherita, Pavia, on August 1, 2013, with this admission diagnosis: patient with PEJ from April 2013, esophageal and gastric necrosis from caustic soda ingestion with results of gastrectomy and jejunostomy. In conjunction with a clinical evaluation based on patient history, it was take into account a depressive syndrome, total esophagectomy, pharyngolaryngectomy, pharyngealcolon-ileal anastomosis, bearer of tracheostomy, and with an history of previous cholecystectomy and appendectomy. Written informed consent was obtained from the patient as well as this case report was performed according to the Declaration of Helsinki and approved by Institute of Geriatric Rehabilitation Santa Margherita institutional review board.

\section{First stage of nutritional intervention}

At the initial nutritional assessment on admission, the patient was categorized as "patient with a severe malnutrition", with serum albumin of $3.15 \mathrm{mg} / \mathrm{dL}$, body mass index (BMI) of $17.3 \mathrm{~kg} / \mathrm{m}^{2}$ (50 kg for $1.70 \mathrm{~m}$ ), Mini Nutritional Assessment (MNA) equal to 10 points, and weight loss of $\sim 5.2 \%$ in the previous 6 months. The score of Activities of Daily Living (ADL) was 2 points, which showed that nutritional difficulties restricted the ability to perform self-care activities. In particular, the patient was not able to maintain an independent life, such as needs help in bathing and in moving from bed to chair. Other parameters, at baseline and in the time progression, are shown in Table 1.

The nutrition support team recommended to continue the use of the PEJ; therefore, the patient received a polymer and high-caloric formula, with an elevated content of soluble fibers from partially hydrolyzed guar gum (PHGG) $(500 \mathrm{~mL} \times 2,1.5 \mathrm{kcal} / \mathrm{mL}, 6.0 \mathrm{~g}$ proteins $/ 100 \mathrm{~mL}, 18.3 \mathrm{~g}$ carbohydrates $/ 100 \mathrm{~mL}, 5.9 \mathrm{~g}$ lipids $/ 100 \mathrm{~mL}$, and $2.2 \mathrm{~g}$ PHGG/100 mL), indicated for patients with a sole source of nutrition on medical grounds (eg, short bowel syndrome), following total gastrectomy and disease-related malnutrition. Other nutritional characteristics of this formula are listed in Table 2. The elected speed of the enteral nutrition (EN) was $80 \mathrm{~mL} / \mathrm{h}$, because the patient was already under artificial nutrition from April 2013. The formula was well tolerated during hospitalization ( 2 months), there were no episodes of diarrhea or vomiting, and the weight remained stable.

\section{Second stage of nutritional intervention}

The patient was again hospitalized on November 5, 2013, for a medium-/long-term complication, which was local infection, pain, diarrhea, and malnutrition. At the nutritional assessment, the following parameters were detected: serum albumin of $3.76 \mathrm{mg} / \mathrm{dL}$, BMI of $17.3 \mathrm{~kg} / \mathrm{m}^{2}$ (50 kg for $1.70 \mathrm{~m}$, weight stable), and MNA equal to 13 points. There was no weight loss between the two admissions; then the nutrition support team recommended to continue the use of the polymer and high-caloric formula, with an elevated content of soluble fiber, PHGG $(500 \mathrm{~mL} \times 2)$. The elected speed of the EN was $60 \mathrm{~mL} / \mathrm{h}$ (initially decreased due to diarrhea) and was recommended to increase the speed of $20 \mathrm{~mL} / \mathrm{h}$ up to $120 \mathrm{~mL} / \mathrm{h}$, given the good tolerance of the patient to the formula in the previous admission. The patient responded well and continued this formula, by increasing the speed for 1 month.

Table I Progression of clinical and laboratory parameters of the patient

\begin{tabular}{|c|c|c|c|c|}
\hline Parameters & $\begin{array}{l}\text { First stage - } \\
\text { August } 2013\end{array}$ & $\begin{array}{l}\text { Second stage - } \\
\text { November } 2013\end{array}$ & $\begin{array}{l}\text { Third stage - } \\
\text { December } 2013\end{array}$ & $\begin{array}{l}\text { Reference } \\
\text { standard values }\end{array}$ \\
\hline Body weight, kg & 50 & 50 & 50 & $53.5-72$ \\
\hline BMI, kg/m² & 17.3 & 17.3 & 17.3 & $18.5-24.9$ \\
\hline Total protein, g & 6.1 & 6.9 & 6.1 & $6.0-8.2$ \\
\hline Serum albumin, g/dL & 3.15 & 3.76 & 3.34 & $3.5-4.8$ \\
\hline Cholesterol, mg/dL & 136 & 156 & 144 & $<200$ \\
\hline Lymphocyte, $10^{3} / \mu \mathrm{L}$ & 1.95 & 1.72 & 1.93 & $0.8-3.6$ \\
\hline Glycemia, mg/dL & III & 93 & 78 & $70-110$ \\
\hline MNA score & 10 & 13 & 16 & $>23.5$ \\
\hline ADL score & 2 & - & 5 & $0-6$ \\
\hline
\end{tabular}

Abbreviations: BMI, body mass index; MNA, Mini Nutritional Assessment; ADL, activities of daily living. 
Table 2 Nutritional info concerning enteral nutrition formula

\begin{tabular}{|c|c|c|}
\hline Typical values & Per $100 \mathrm{~mL}$ & Per $500 \mathrm{~mL}$ \\
\hline \multicolumn{3}{|l|}{ General } \\
\hline Energy, kJ/kcal & $649 / 155$ & $3,245 / 775$ \\
\hline Protein ( $16 \% \mathrm{kcal}), \mathrm{g}$ & 6 & 30 \\
\hline Carbohydrates (47\% kcal), g & 18.3 & 91.5 \\
\hline Sugars, g & 1.6 & 8.0 \\
\hline Lactose, g & $<0.05$ & $<0.25$ \\
\hline Fat (34\% kcal), g & 5.9 & 29.5 \\
\hline Saturates, $g$ & 1.9 & 9.5 \\
\hline MCT, $g$ & 1.4 & 7 \\
\hline Monounsaturates, $g$ & 2.5 & 12.5 \\
\hline Polyunsaturates, g & I.I & 5.5 \\
\hline Fiber ( $3 \% \mathrm{kcal})$, g & 2.2 & 11 \\
\hline Soluble, g & 2.2 & 11 \\
\hline \multicolumn{3}{|l|}{ Vitamins } \\
\hline $\mathrm{A}, \mu \mathrm{g}$ & 160 & 800 \\
\hline$\beta$-carotene, $\mu \mathrm{g}$ & 38 & 190 \\
\hline $\mathrm{D}, \mu \mathrm{g}$ & 2.2 & 11 \\
\hline $\mathrm{K}, \mu \mathrm{g}$ & 11 & 55 \\
\hline $\mathrm{C}, \mathrm{mg}$ & 16 & 80 \\
\hline BI (thiamin), mg & 0.22 & 1.1 \\
\hline B2 (riboflavin), mg & 0.26 & 1.3 \\
\hline $\mathrm{B} 6, \mathrm{mg}$ & 0.27 & 1.35 \\
\hline Niacin, mg & 3 & 15 \\
\hline Folic acid, $\mu \mathrm{g}$ & 45 & 225 \\
\hline $\mathrm{BI} 2, \mathrm{mg}$ & 0.58 & 2.9 \\
\hline Pantothenic acid, mg & 0.92 & 4.6 \\
\hline Biotin, $\mu g$ & 7 & 35 \\
\hline $\mathrm{E}, \mathrm{mg}$ & 2.9 & 14.5 \\
\hline \multicolumn{3}{|l|}{ Minerals } \\
\hline Sodium, mg/mmol & $120 / 5.22$ & $600 / 26.1$ \\
\hline Chloride, $\mathrm{mg} / \mathrm{mmol}$ & $150 / 4.23$ & $750 / 21.15$ \\
\hline Potassium, $\mathrm{mg} / \mathrm{mmol}$ & $135 / 3.46$ & $675 / 17.3$ \\
\hline Calcium, mg/mmol & $80 / 2$ & $400 / 10$ \\
\hline Phosphorus, $\mathrm{mg} / \mathrm{mmol}$ & $75 / 2.42$ & $375 / 12.10$ \\
\hline Magnesium, $\mathrm{mg} / \mathrm{mmol}$ & $30 / 1.25$ & $150 / 6.25$ \\
\hline Iron, mg & 1.6 & 8 \\
\hline Zinc, mg & 1.8 & 9 \\
\hline Copper, $\mu g$ & 240 & $\mathrm{I}, 200$ \\
\hline lodine, $\mu g$ & 22 & 110 \\
\hline Selenium, $\mu \mathrm{g}$ & 10 & 50 \\
\hline Manganese, mg & 0.36 & 1.8 \\
\hline Chromium, $\mu \mathrm{g}$ & 15 & 75 \\
\hline Molybdenum, $\mu \mathrm{g}$ & 20 & 100 \\
\hline Fluoride, mg & 0.16 & 0.8 \\
\hline \multicolumn{3}{|l|}{ Other nutrients } \\
\hline Choline, mg & 57 & 285 \\
\hline Water, g & 76 & - \\
\hline Osmolarity, mOsm/L & 389 & - \\
\hline Osmolarity, mOsm/kg & 440 & - \\
\hline
\end{tabular}

Abbreviation: $\mathrm{MCT}$, medium chain triglyceride.

\section{Third stage of nutritional intervention}

On December 10,2013, a computed tomography was performed to exclude the presence of adhesions and the regular passage of the bolus.
Hence, the medical team removed the PEJ, and the patient switched from EN to oral nutrition. At the nutritional assessment, the serum albumin was $3.34 \mathrm{~g} / \mathrm{dL}$, the BMI was $17.3 \mathrm{~kg} / \mathrm{m}^{2}$ (50 kg for $1.70 \mathrm{~m}$, weight stable), and the MNA was equal to 16 points. Other parameters are shown in Table 1. The patient reported that he began to do breakfast with a cup of milk and rusks, eating fruits and vegetables two times a day, and meat and fish every day.

Generally, the risk of decline in ADL increases markedly in this stage, then, the nutrition support team decided to introduce two oral high-caloric supplements: an energy supplement in powder, based on maltodextrin, immediately soluble in foods, hot/cold drinks, and sweet/savory drinks (six servings a day with the measuring cup; $5 \mathrm{~g}$ for three measuring cups in the first course at lunch and three measuring cups in the first course at dinner, $120 \mathrm{kcal}$ ) and a liquid energy-protein supplement (a formula with high energy, protein, and enriched with arginine, vitamin $\mathrm{C}$, zinc, and antioxidants).

After 1 month, on January 15, 2014, the patient was discharged from the institute and was able to eat a regular meal instead of artificial nutrition. The ADL score of 5 points showed that the patient was able to undertake self-care.

In summary, the progression in time of the nutritional intervention from artificial to oral nutrition is shown in Table 3.

\section{Discussion}

The ingestion of corrosive industrial chemical agents, such as caustic soda, that are mostly used for household cleaning, usually occurs accidentally or sometimes for suicidal purposes. Nutritional interventions in these situations may be important for life expectancy. At the first stage, nutritional management must be set up on EN. In a patient with esophageal and gastric necrosis, the use of a high-proteinspecific formula with a similar caloric percentage of fat and carbohydrates brings about an improvement in both nutritional status and biochemical parameters.

This formula should bring about at least $150 \%$ of recommended daily amount (RDA) intake in vitamin C (systemic inflammation and damage attenuations both in vivo and in vitro); ${ }^{3} 100 \%$ of RDA intake in vitamin $\mathrm{D}$ (effects on the biomarkers of inflammation and endothelial activation [high sensitivity C-reactive protein and endothelin-1] and flowmediated dilation); ${ }^{4}$ and $150 \%$ of RDA of folate, vitamins B1, B2, and B12. As shown in a recent study, these vitamins decrease the marked inflammation and apoptosis, despite activation of repair machinery. ${ }^{5}$ In addition, the intake of 
Table 3 Progression of nutritional support of the patient

\begin{tabular}{|c|c|c|c|}
\hline Hospital stay & Clinical aspects & Oral diet & Enteral feeding/ONS \\
\hline August 2013 & $\begin{array}{l}\text { No episodes of diarrhea } \\
\text { or vomiting; weight } \\
\text { remained stable }\end{array}$ & - & $\begin{array}{l}\text { Jejunal feeding: polymeric, high-caloric } \\
\text { formula with an elevated content of soluble } \\
\text { fiber partially hydrolyzed guar gum (PHGG) } \\
\text { with a speed of } 80 \mathrm{~mL} / \mathrm{h}\end{array}$ \\
\hline November 2013 & $\begin{array}{l}\text { No episodes of diarrhea } \\
\text { or vomiting; weight } \\
\text { remained stable }\end{array}$ & - & $\begin{array}{l}\text { Jejunal feeding: polymeric, high-caloric } \\
\text { formula with an elevated content of soluble } \\
\text { fiber PHGG with an initial speed of } 60 \mathrm{~mL} / \mathrm{h} \\
\text { and up to } 120 \mathrm{~mL} / \mathrm{h}\end{array}$ \\
\hline December 2013 & Subjective well-being & $\begin{array}{l}\text { Regular meal: through the consume of } \\
\text { homogenized fish (four times per week), } \\
\text { poultry meal (three times per week), and } \\
\text { fruits and vegetables }\end{array}$ & $\begin{array}{l}\text { Two high-caloric supplements: an } \\
\text { energy supplement in powder based on } \\
\text { maltodextrin and a high-energy and protein } \\
\text { drink, enriched with arginine, vitamin C, } \\
\text { zinc, and antioxidants }\end{array}$ \\
\hline
\end{tabular}

Abbreviation: ONS, oral nutritional supplements.

minerals, zinc in particular, might suppress the generation of inflammatory cytokines and reactive oxygen species damage. ${ }^{6}$ The advantage of this approach is its safety in terms of infection. For the first 3 months, the EN infusion speed should be stable at $\sim 80 \mathrm{~mL} / \mathrm{h}$. In this case report, the best improvements are highlighted 3 months later, when the infusion speed was set up to $120 \mathrm{~mL} / \mathrm{h}$, in the absence of diarrhea. Most previous works concerning the characteristics and the EN infusion speed have concentrated on the risk of infectious of diarrhea, due to either the enteral feeding equipment or the sterility of the formula. ${ }^{7}$

In our study, after 4 months, we removed the PEJ and we decided to introduce two oral, high-caloric daily supplements: an energy supplement in powder, based on maltodextrin, immediately soluble in foods (or in hot/cold drinks) and a high-energy and protein drink, enriched with arginine, vitamin $\mathrm{C}$, zinc, and antioxidant. Previous to our experience and considering the literature, absorption of glucose and fat from the maltodextrin diet was significantly greater than that from the glucose diet, whereas absorption of protein was only slightly enhanced. ${ }^{8}$ In addition, introducing different antioxidants such as $\alpha-, \beta-, \gamma$-carotene, lycopene, luteina, and zeaxantina may improve tissue repairing process. ${ }^{9}$

Initially, we considered a supplementation of omega 3, following The American Dietetic Association Guidelines that recommend consuming $500 \mathrm{mg} / \mathrm{d}$ of a combination of EPA (eicosapentaenoic acid) and DHA (docosahexaenoic acid). ${ }^{10}$ However, this procedure caused side effects, including upset stomach, loose stools, and belching. In addition to this, oral administration was well tolerated, thanks to consuming of homogenized fish (four times per week), poultry meal (three times per week), and fruits and vegetables every day, all diluted in water. In scientific literature, there are no guidelines for the nutritional support of patients with gastric and esophageal necrosis due to ingestion of corrosive industrial chemical agents for suicidal purpose. The correct choice of the most appropriate nutritional support varies from patient to patient, and many factors are determined. By using a personalized formula, through PEJ, the weight loss could reduce for some patients, preventing the transition to cachexia. Moreover, the choice of specific nutrients allows to repair tissues with necrosis and to decrease the inflammatory state. In all patients with no adhesions and the regular passage of the bolus, the removal of the PEJ is indicated, with the combination of homogenized meal and dietary supplements.

\section{Conclusion}

In conclusion, this is the first case of a nutritional approach to follow patients with esophageal and gastric necrosis; it allows reducing the risks of malnutrition or infection, which can lead to negative outcome of the patient.

\section{Disclosure}

The authors report no conflicts of interest in this work.

\section{References}

1. Johnson CM, Brigger MT. The public health impact of pediatric caustic ingestion injuries. Arch Otolaryngol Head Neck Surg. 2012;138(12): $1111-1115$.

2. Anderson KD, Rouse TM, Randolph JG. A controlled trial of corticosteroids in children with corrosive injury of the esophagus. N Engl J Med. 1990;323(10):637-640.

3. McCully SP, Martin DT, Cook MR, et al. Effect of ascorbic acid concentrations on hemodynamics and inflammation following lyophilized plasma transfusion. J Trauma Acute Care Surg. 2015;79(1):30-38.

4. Struglia M, Stamerra CA, Di Giosia P, et al. 6D.06: vitamin D deficiency and endothelial dysfunction in rheumatoid arthritis patients. J Hypertens. 2015;33(1):e84. 
5. Bossenmeyer-Pourié C, Pourié G, Koziel V, et al. Early methyl donor deficiency produces severe gastritis in mothers and offspring through N-homocysteinylation of cytoskeleton proteins, cellular stress, and inflammation. FASEB J. 2013;27(6):2185-2197.

6. Prasad AS, Bao B, Beck FW, Sarkar FH. Zinc-suppressed inflammatory cytokines by induction of A20-mediated inhibition of nuclear factor-KB. Nutrition. 2011;27(7):816-823.

7. Luft VC, Beghetto MG, De Mello ED, Polanczyk CA. Role of enteral nutrition in the incidence of diarrhea among hospitalized adult patients. Nutrition. 2008;24:528-535.
8. Weber E, Ehrlein HJ. Glucose and maltodextrin in enteral diets have different effects on jejunal absorption of nutrients, sodium and water and on flow rate in mini pigs. Dtsch Tierarztl Wochenschr. 1998;105(12):446-449.

9. Weintraub $\mathrm{H}$. Update on marine omega-3 fatty acids: management of dyslipidemia and current omega-3 treatment options. Atherosclerosis. 2013;230(2):381-389.

10. Cereda E, Klersy C, Serioli M, Crespi A, D’Andrea F; OligoElement Sore Trial Study Group. A nutritional formula enriched with arginine, zinc, and antioxidants for the healing of pressure ulcers: a randomized trial. Ann Intern Med. 2015;162(3):167-174.

\section{Publish your work in this journal}

Therapeutics and Clinical Risk Management is an international, peerreviewed journal of clinical therapeutics and risk management, focusing on concise rapid reporting of clinical studies in all therapeutic areas outcomes, safety, and programs for the effective, safe, and sustained use of medicines. This journal is indexed on PubMed Central, CAS
EMBase, Scopus and the Elsevier Bibliographic databases. The manuscript management system is completely online and includes a very quick and fair peer-review system, which is all easy to use. Visit http://www.dovepress.com/testimonials.php to read real quotes from published authors.

Submit your manuscript here: http://www.dovepress.com/therapeutics-and-clinical-risk-management-journal 